Uşak Üniversitesi Sosyal Bilimler Dergisi

$2015,8 / 4$

\title{
Sınıf Öğretmeni Adaylarının Gazete ve Dergi Takip Etme Alışkanlıkları ile Medya Okuryazarlık Düzeyleri Arasındaki İlişsi*
}

\author{
Eyüp YILMAZ \\ Soner ALADAĞ $\breve{G}^{* * *+}$
}

\section{Öz}

$\mathrm{Bu}$ araştırmanın amacı, sınıf öğretmeni adaylarının gazete ve dergi takip etme alışkanlıkları ile medya okuryazarlık düzeyleri arasındaki ilişkiyi belirlemektir. İliş̧kisel tarama modeline göre desenlenen araştırmanın evrenini Türkiye'deki üniversitelerin Sınıf Öğretmenliği Anabilim Dalı'nda öğrenim gören sınıf öğretmeni adayları oluştururken, örneklem grubunu Adnan Menderes Üniversitesi Eğitim Fakültesi Sınıf Öğretmenliği Anabilim Dalı'nda öğrenim gören 579 sınıf öğretmeni adayı oluşturmaktadır. Araştırmada veri toplamak amacıyla Korkmaz ve Yeşil (2011) tarafından geliştirilen "Medya ve Televizyon Okuryazarlık Düzeyleri Ölçeği" gerekli izinler alındıktan sonra kullanılmıştır. Araştırma sonucunda kadın öğretmen adaylarının erkek adaylara göre daha fazla gazete ve dergi takip etme alışkanlığına sahip olduğu; 4. sınıf öğrencilerin medya okuryazarlık düzeylerinin 1. sinıf öğrencilerin medya okuryazarlık düzeylerinden daha yüksek olduğu, öğretmen adaylarının gazete takip etme alışkanlıkları ile medya okuryazarlık düzeyleri arasında anlamlı ve pozitif bir ilişki olduğu ve gazete takip etme alışkanlıklarının medya okuryazarlık düzeylerini yordadığı bulunmuştur.

Anahtar Kelimeler: Medya, Medya Okuryazarlı̆̆ı, Gazete, Dergi.

* Bu çalışma Yılmaz (2013) Yüksek Lisans tezinden üretilmiştir ve 13. Sınıf Öğretmenliği Kongresinde sözlü bildiri olarak sunulmuştur.

** Arş. Gör., Gazi Üniversitesi, Gazi Eğitim Fakültesi, Sınıf Öğretmenliği Anabilim Dalı, Türkiye, eyupyilmaz@gazi.edu.tr

*** Yrd. Doç. Dr., Adnan Menderes Üniversitesi, Eğitim Fakültesi, Sınıf Öğretmenliği Anabilim Dalı, Türkiye, soneraladag@yahoo.com 


\title{
Relationship Between Primary School Teaching Prospective Teachers' Habits of Reading Periodical Publications and Media Literacy
}

\begin{abstract}
The aim of this study is to determine the prospective students' habits of following newspaper and magazine and to determine the relationships between these habits and media literacy levels. The research model has the features of descriptive-relational survey model, one of the general survey models. The population consists of prospective primary teachers who are studying at all education faculties in Turkey. Sample of study consists of 579 prospective primary school teachers of department of primary school teacher education in Adnan Menderes University. "Media and Television Literacy Levels Scale" developed by Korkmaz and Yesil (2011) were used to collect data in the research after getting the necessary permissions. As a result of the research, it can be said that females' habits of following newspapers and journals are superior to males' habits, and fourth grade prospective teachers level of media literacy is higher than first grade prospective teachers. There is a significant and positive relationship between prospective teachers' habit of following journals and their media literacy level and also, it has been found that prospective teachers' habit of following newspaper predicts their media literacy levels.
\end{abstract}

Keywords: Media, Media Literacy, Newspaper, Journal.

\section{Giriş}

XX. yüzyıldan itibaren bireylerin medya ile etkileşimi daha da artmakta ve bununla birlikte medya iletilerine her geçen gün artan bir yoğunlukta maruz kaldıkları görülmektedir (Kıncal ve Kartal, 2009). Her geçen gün ilerleyen teknolojik gelişmeler internet okuryazarlığı, dijital okuryazarlık, medya okuryazarlığı gibi çeşitli okuryazarlık kavramlarını gündeme getirmiştir (Livingstone, 2008). Uluslararası Okuma Derneği (International Reading Association) 2009 yılında okuryazarlığ1 tanımlarken; günümüz dünyasında iyi bir okuryazar olmak için öğrencilerin 21. yüzyıl okuryazarlık teknolojilerini ustaca kullanabilmesinin gerektiğinden bahsetmektedir (Teo, 2014). Okuryazarlık tanımı artık bilgiye erişme, bilgiyi işleme ve bilgi aktarımı gibi dijital süreçlerin içermektedir (Collier, Foley, Moguel ve Barnard, 2013). Bu bağlamda okuryazarlık becerisinin aynı zamanda dijital okuryazarlık, bilgi okuryazarlığı, medya okuryazarlığı gibi çeşitli okuryazarlık becerilerine de sahip olmayı gerektirdiği söylenebilir. 
Medya okuryazarlığı ise adından da anlaşılacağı üzere, gündelik hayatta karşı karşıya olduğumuz televizyon, gazete, radyo, bilgisayar, dergi ve reklamlardan görsel ve sözsel semboller çıkarma yeteneğidir (Thoman, 1999). Medya okuryazarlık eğitimi öğretmenlerin öğrencilerine çözümleme analiz, değerlendirme ve çeşitli formlardan yararlanarak yeni bilgiler üretme gibi becerileri kazandırmasını gerektirmektedir (Aufderheide ve Firestone, 1993; Carnegie Council, 1995; akt. Stein ve Prewett, 2009). Hobbs öğrencilerin modern kültüre kolay bir şekilde uyum sağlayabilmeleri için 21. yy medya okuryazarlığı becerilerine sahip olması gerektiğinden; aynı zamanda bu becerilere öğretmenlerin ve öğrencilerin yaşam boyu öğrenme sürecinde ihtiyaç duyduklarından bahsetmektedir (Blumberg).

Bu beceriler;

1. Erişim becerisi: Dinleme, okuduğunu anlama gibi becerilerin yanı sıra klavye, fare, arayüz kullanma, dijital alanla bă̆ kurma ve etkili araştırma ve strateji bulma gibi alt becerileri içermektedir.

2. Analiz becerisi: Yazarın amacını ve vermek istediği mesajı belirleyebilme, iletinin güvenirliğini ve kalitesini değerlendirebilme, tanımlayabilme ve basmakalıp yargılara direnç gösterebilme gibi alt becerileri içermektedir.

3. Yaratıcılık ve İşbirliği Becerisi: Beyin fırtınası, fikir üretme, ileti üretebilmek için işbirliği yapma, geri bildirim, dönüt ve düzeltme gibi alt becerileri kapsamaktadır.

4. Yansıtma ve Harekete Geçme: Bu beceriler insanların, iletişim gücü bilgisiyle statükoyu korumak ya da dünyayı değiştirmek; medya mesajlarını zararlarm ve potansiyel risklerini dikkate almak; ve insanları medya kullanımlarmın ve medya mesajlarına yönelik yorumlarının onların yaşamlarında ve değerlerinde ne gibi değgişikliklere neden olduğunu anlayabilmeleri gibi üst bilişsel beceri kapsamaktadır.

Medya okuryazarlı̆̆ fikrinin 50 yıllık bir geçmişi olmasına rağmen Türkiye'de bir hayli geç kalındığı söylenebilir (Altun, 2008). Medya okuryazarlığı ve bu konuda eğitim verme tartışmaları ülkemizde 2000'li yılların başlarına dayanmaktadır (Hasdemir, 2012). Buna rağmen RTÜK ve MEB işbirliğinde başlatılan projenin önemi göz ardı edilemez. Proje kapsamında medya okuryazarlığı dersinin ilköğretim ikinci kademede 2004 yılından itibaren seçmeli ders olarak okutulması kararlaştııılmıştır. Bireylerin medya okuryazarlığı becerisine sahip olabilmesi için öncelikle eleştirel okuryazarlık becerilerinin gelişmesi gerekmektedir.

Eleştirel okuryazarlık demokratik ortamda çok önemlidir. Eleştirel yaklaşımı olmayan bireyler sadece iletileri alan bireydir. Eleştirel beceriler 
bireyi, medya kullanıcısı olarak pasif durumdan aktif duruma, alıcıdan katılımcı duruma, tüketiciden vatandaş durumuna dönüştürür (Livingstone, 2004). Eleştirel medya okuryazarlığı sadece bireyin medyadan nasıl öğreneceklerini, medya yönlendirmelerine karşı koymayı öğretmeyi sağlamaz; ayrıca bireyleri sosyal hayatta daha katılımcı yapacak olan ve iyi bir vatandaş yaratmayı sağlayacak becerilerin gelişmesini de sağlar (Kellner ve Share, 2005). Eleştirel medya okuryazarlığı, analitik becerilerden daha fazlasını gerektirmektedir. Basılı resimler, fotoğraflar, elektronik görsel resimlerden türetilmiş mesajların farkına varma, mesajlara anlamların nasıl yüklendiğini anlama, bunları okuma ve yorumlama yeteneğidir (Semali ve Hammlett, 1998).

Dünya Gazeteler Birliği (WAN) verilerine göre 1000 kişi başına 600'den fazla net satışla dünyada kişi başına en çok gazete satılan ülke Norveç. Bu ülkeyi Japonya, Finlandiya, İşveç, Danimarka, İsviçre, Avusturya, Kanada, Almanya, Hollanda, İngiltere ve ABD izlemektedir. Türkiye'de ise her 1000 kişiye 73 gazete düşmektedir. (http://www.medyatava.com/haber/dunyada-ilk-100-gazete-iste-dunyagazeteler-birliginin-verileriğ27955).

Finlandiya, Danimarka, Kanada, ABD vb. gazete okuma oranlarının yüksek olduğu ülkelerde medya okuryazarlı̆ğ eğitimlerinin çok daha köklü ve ileri seviyede olması (Altun, 2010; Binark ve Bek, 2007; Çakmak, 2010; Kubey, 1998) medya okuryazarlık becerisi ile gazete ve dergi okuma alışkanlıkları arasındaki ilişkinin belirlenmesini ihtiyaç kılmaktadır.

Bireylerin okul çağı döneminde öğretmenleri tarafından yönlendirilmeleri, güdülenmeleri ve desteklenmeleri okuma alışkanlığı kazanmasında oldukça önemlidir (Bozpolat, 2010). Tosunoğlu (2002: 556558) tarafından yapılan bir araştırmada, çocuklara kitap okuma düşüncesini aşılamada en büyük etkiyi \%70,7'lik bir oranla öğretmenlerin yaptığı, aynı şekilde öğrencilere ilk kitaplarını \%33,0 oranıyla sınıf öğretmenlerinin verdiği tespit edilmiştir (Akt. Özbay, Bağcı ve Uyar, 2008: 120). Dolayısıyla okuma alışkanlığı kazandırılmasında sınıf öğretmenlerine önemli görevler düşmektedir.

$\mathrm{Bu}$ araştırmada da sınıf öğretmeni adaylarının gazete ve dergi takip etme alışkanlıkları ile medya okuryazarlık düzeyleri arasındaki ilişki belirlenmeye çalışılmıştır.

\section{Araştırmanın Amacı}

$\mathrm{Bu}$ araştırmanın amacı, sınıf öğretmeni adaylarının gazete ve dergi takip etme alışkanlıkları ile medya okuryazarlık düzeyleri arasındaki ilişkiyi 
belirlemektir. $\mathrm{Bu}$ amaca ulaşabilmek için aşağıdaki alt amaçlara cevap aranmıştır:

1. Sınıf öğretmeni adaylarının gazete ve dergi takip etme alışkanlıkları, cinsiyetlerine ve sinıf düzeylerine göre anlamlı farklılık göstermekte midir?

2. Sınıf öğretmeni adaylarının medya okuryazarlığı düzeyleri, cinsiyetlerine ve sinıf düzeylerine göre anlamlı farklılık göstermekte midir?

3. Sınıf öğretmeni adaylarının gazete ve dergi takip alışkanlıkları ile medya okuryazarlık düzeyleri arasındaki ilişki nasıldır?

4. Sınıf öğretmeni adaylarının gazete ve dergi takip etme alışkanlıkları medya okuryazarlık düzeylerini yordamakta mıdır?

\section{Yöntem}

Sınıf öğretmeni adaylarının gazete ve dergi takip etme alışkanlıkları ile medya okuryazarlık düzeyleri arasındaki ilişkiyi belirlemeyi amaçlayan bu araştırma ilişkisel tarama modeli özelliklerine sahiptir. İlişkisel (korelasyonel) tarama modelleri, iki ve daha çok sayıdaki değişken arasında birlikte değişim varlığını ve/veya derecesini belirlemeyi amaçlayan araştırma modelleridir. (Karasar, 2011).

\section{Evren ve Örneklem}

Araştırmanın evrenini Türkiye'deki üniversitelerin Sınıf Öğretmenliği Anabilim Dalında öğrenim gören sınıf öğretmeni adayları oluşturmaktadır. Adnan Menderes Üniversitesi Eğitim Fakültesi Sınıf Öğretmenliği Anabilim Dalında öğrenim gören 579 öğretmen adayı çalışmanın örneklem grubunu oluşturmaktadır. Örneklem grubu amaçsal örnekleme yaklaşımlarından tipik durum örnekleme yöntemi ile belirlenmiştir. Bu örnekleme yöntemi, araştırma problemi ile ilgili olarak evrende yer alan çok sayıdaki durumdan tipik olan bir durumun belirlenerek bu örnek üzerinden bilgi toplanmasını gerektirir (Büyüköztürk, Kılıç Çakmak, Akgün, Karadeniz ve Demirel, 2011). Örneklem grubuna ilişkin ayrıntılı betimsel bilgiler aşağıda verilmiştir.

Tablo 1. Sınıf Öğretmeni Adaylarının Cinsiyete Göre Dağılımları

\begin{tabular}{ccc}
\hline Cinsiyet & $\mathbf{n}$ & $\mathbf{\%}$ \\
\hline Kadın & 392 & 67,7 \\
Erkek & 187 & 32,3 \\
Toplam & 579 & 100 \\
\hline
\end{tabular}


Araştırmaya katılan 579 sınıf öğretmeni adayının \% 67,7'si (N=392) kadın öğretmen adayından, \%32.3'ü (N=187) ise erkek öğretmen adayından oluşmaktadır. Araştırmaya katılan kadın aday sayısının, erkek aday sayısının iki katından daha fazla olduğu görülmektedir. Bu durum sınıf öğretmenliğinde okuyan kadın öğrenci sayısının erkek öğrenci sayısından daha fazla olmasından kaynaklanmaktadır.

Tablo 2. Sınıf Öğretmeni Adaylarının Sınıf Düzeylerine Göre Dağılımı

\begin{tabular}{lll}
\hline Sınıf Düzeyi & $\mathbf{n}$ & $\mathbf{\%}$ \\
\hline 1 & 84 & 14,5 \\
2 & 166 & 28,7 \\
3 & 175 & 30,2 \\
4 & 154 & 26,6 \\
Toplam & 579 & 100 \\
\hline
\end{tabular}

Araştırmaya katılan 579 sınıf öğretmeni adaylarının \% 14,5'i (N=84) 1. sinifta, $\% 28,7^{\prime}$ si $(\mathrm{N}=166)$ 2. sinifta, \% 30,2'si ( $\left.\mathrm{N}=175\right) 3$. sinifta ve $\% 26,6^{\prime}$ si $(\mathrm{N}=154)$ 4. sinıfta öğrenim görmektedir. Birinci sinıf mevcudunun diğer sınıflara göre daha az olmasının nedeni birinci sınıfların ikinci öğretim siniflarının olmamasıdır.

\section{Veri Toplama Araci}

Araştırmada sınıf öğretmeni adaylarının medya okuryazarlık düzeylerini belirlemek amaciyla Korkmaz ve Yeşil (2011) tarafından geliştirilen "Medya ve Televizyon Okuryazarlık Düzeyleri Ölçeği" kullanılmıştır. Medya ve Televizyon Okuryazarlık Düzeyleri Ölçeği "Okuryazarlık (13 madde)" ve "Bağımlılık (5madde)" boyutlarından oluşmaktadır. "Okuryazarlık" boyutunun Cronbach alpha güvenirlik katsayısı .914 olarak hesaplanırken, "Bağımlılık" boyutunun Cronbach alpha güvenirlik katsayısı .851 olarak hesaplanmıştır. Tüm ölçeğin Cronbach alpha güvenirlik katsayısı ise .847 olarak hesaplanmıştır. "Okuryazarlık" boyutunda yer alan maddelerin faktör yük değerleri ".484 - .774 arasında değişirken; "bağımlılık" boyutunda yer alan maddelerin faktör yük değerleri .662 - .826 arasında değişmektedir.

\section{Verilerin Çözümlenmesi ve Yorumlanması}

Araştırmada veri toplama araçları ile elde edilen verilerin istatistiksel analizinde SPSS 18.0 paket programından yararlanılmıştır. Uygulamaya katılan sınıf öğretmeni adaylarının gazete ve dergi takip etme 
alışkanlıkları onların cinsiyetlerine, sınıf ve aile gelir düzeylerine göre farklılık gösterip göstermediğini bulmak amacıyla nanparametrik testlerden "kay-kare (chi-square)" testi yapılmıştır. Bu teknik iki sınıflamalı (kategorik) değişken arasında anlamlı bir ilişki olup olmadığını test eder. Analiz, biri sınıflamalı diğeri sıralamalı olan iki değişken arasında anlamlı bir ilişkinin olup olmadığını test etmek için de kullanılır (Büyüköztürk vd., 2011).

Uygulamaya katılan sınıf öğretmeni adaylarının medya okuryazarlık düzeylerinin onların cinsiyetlerine, sınıf düzeylerine ve aile gelir düzeylerine göre anlamlı farklılık gösterip göstermediğini bulmak amaciyla "t testi" ve "Tek Yönlü Varyans Analizi (One way ANOVA)"; adayların medya okuryazarlık düzeyleri ile gazete - dergi takip etme sıklıkları arasındaki ilişkiyi belirlemek amacıyla çift serili korelasyon katsayısı bulunmuştur. Bu korelasyon katsayısı sürekli iki değişkenden birinin aslında sürekli iken yapay olarak kategorili hale getirilmesi durumunda kullanılır (Baykul ve Güzeller, 2014). Adayların gazete-dergi takip etme sıklıklarının onların medya okuryazarlık düzeylerini yordayıp yordamadığını belirlemek amacıyla lojistik regresyon analizi yapılmıştır. Lojistik regresyon, bağımsız değişkenin sürekli ya da nicel bir değişken olmadığı, bir diğer deyişle kategorik ya da sinıflamalı olduğu durumlar için uygun bir analiz türüdür (Long, 1997; Mertler ve Vannatta, 2005'dan aktaran Çokluk, Şekercioğlu ve Büyüköztürk, 2012). Bunun bir sonucu olarak da lojistik regresyon, doğrusal regresyon modellerindeki temel sayıltıların karşılanması gerektirmez (Çokluk, Şekercioğlu ve Büyüköztürk, 2012).

\section{Bulgular}

\section{Adayların Cinsiyet ve Sinıf Düzeylerine Göre Gazete ve Dergi Takip Etme Alışkanlıkları}

Sınıf öğretmeni adaylarının gazete ve dergi takip etme alışkanları, cinsiyetlerine ve sınıf düzeylerine göre anlamlı farklılık göstermekte midir? Alt amacına yönelik yapılan Kay Kare (Chi-Square) analizi sonuçları Tablo 3 ve Tablo 4 'te verilmiştir. 
Tablo 3. Cinsiyet ve Sınıf Düzeylerine Göre Gazete Takip Etme Alışkanlıkları

\begin{tabular}{|c|c|c|c|c|c|c|c|c|c|}
\hline & & $\begin{array}{l}\text { Her } \\
\text { gün }\end{array}$ & $\begin{array}{l}\text { İki } \\
\text { günde } \\
\text { bir }\end{array}$ & $\begin{array}{l}\text { Haftada } \\
1 \text { - } 2 \text { defa }\end{array}$ & $\begin{array}{l}\text { Ayda } \\
1-2 \\
\text { defa }\end{array}$ & Hiç & Toplam & \multirow[t]{2}{*}{$\chi^{2}$} & \multirow[t]{2}{*}{$p$} \\
\hline & & $f$ & $f$ & $f$ & $f$ & $f$ & $f$ & & \\
\hline \multirow{3}{*}{ 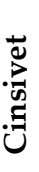 } & Kadın & 75 & 57 & 158 & 86 & 16 & 392 & \multirow{3}{*}{$\begin{array}{l}12.5 \\
2\end{array}$} & \multirow{3}{*}{.014} \\
\hline & Erkek & 58 & 27 & 68 & 26 & 8 & 187 & & \\
\hline & $\begin{array}{l}\text { Top- } \\
\text { lam }\end{array}$ & 133 & 84 & 226 & 112 & 24 & 579 & & \\
\hline \multirow{5}{*}{ 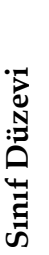 } & 1 & 15 & 15 & 36 & 15 & 3 & 84 & \multirow{5}{*}{9.49} & \multirow{5}{*}{.660} \\
\hline & 2 & 32 & 21 & 63 & 41 & 9 & 166 & & \\
\hline & 3 & 44 & 26 & 68 & 30 & 7 & 175 & & \\
\hline & 4 & 42 & 22 & 59 & 26 & 5 & 154 & & \\
\hline & $\begin{array}{l}\text { Top- } \\
\text { lam }\end{array}$ & 133 & 84 & 226 & 112 & 24 & 579 & & \\
\hline
\end{tabular}

Tablo 3 verileri incelendiğinde kadın ve erkek öğretmen adaylarının gazete takip etme alışkanlıkları arasında anlamlı bir farklılık olduğu $\left(X^{2}=12.52, \quad \mathrm{p}<.05\right)$ ve kadın öğretmen adaylarının erkek öğretmen adaylarından daha sık gazete takip ettiği görülmektedir. Adayların gazete takip etme alışkanlıkları sınıf düzeyine göre anlamlı derecede farklılaşmadığı görülmektedir $\left(X^{2}=9.49, \mathrm{p}>.05\right)$.

Tablo 4. Cinsiyet ve Sınıf Düzeylerine Göre Dergi Takip Etme Alışkanlıkları

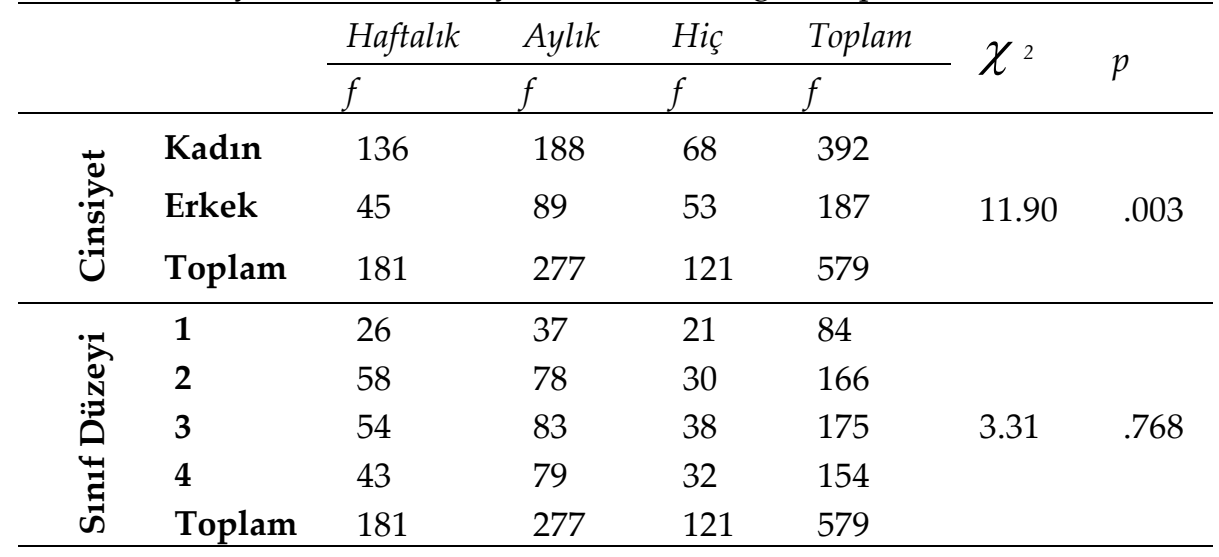

Tablo 4 verileri incelendiğinde kadın ve erkek öğretmen adaylarının dergi takip etme alışkanlıkları arasında anlamlı bir farklılık olduğu $\left(X^{2}=11.90, p<.05\right)$, kadın öğretmen adaylarının erkek öğretmen adaylarından 
daha sık dergi takip ettiği görülmektedir. Adayların dergi takip etme sıklıklarının sınıf düzeyine göre anlamlı derecede farklılaşmadığı görülmektedir ( $\left.X^{2}=3.31, \mathrm{p}>05\right)$.

\section{Adayların Cinsiyet ve Sinff Düzeylerine Göre Medya Okuryazarlık Düzeyleri}

Sınıf öğretmeni adaylarının medya okuryazarlık düzeyleri cinsiyetlerine ve sınıf düzeylerine göre anlamlı farklılık olup olmadığını belirlemek amacıyla yapılan $\mathrm{t}$ testi ve ANOVA sonuçları aşağıda verilmiştir.

Tablo 5. Adayların Medya Okuryazarlık Düzeylerinin Cinsiyete Göre t-Testi Sonuçları

\begin{tabular}{lcccccc}
\hline Cinsiyet & $\mathrm{n}$ & $\overline{\mathrm{X}}$ & $S$ & $\mathrm{sd}$ & $t$ & $p$ \\
\hline Kadın & 391 & 60,04 & 8,21 & & & \\
Erkek & 186 & 61,42 & 8,09 & & & .058 \\
\hline
\end{tabular}

Sınıf öğretmeni adaylarının medya okuryazarlık düzeylerinin cinsiyete göre anlamlı farklılık göstermediği görülmektedir, $[\mathrm{t}(575)=1.89$, $\mathrm{p}>$.05)]. Ancak ulaşılan "p değerinin (.58)" anlamlı farklılık için sınıf kabul edilen ".05" değerine çok yakın olduğu görülmektedir. Dolayısıyla adayların cinsiyetlerine göre anlamlı farklılık çıkmaması örneklemde yer alan kadın adayların sayısının erkek adayların sayısının 2 katından daha fazla olmasından da kaynaklanıyor olabilir.

Tablo 6. Adayların Medya Okuryazarlık Puanlarının Betimsel İstatistikleri

\begin{tabular}{llcc}
\hline Sinıf Düzeyi & $\mathrm{N}$ & $\bar{X}$ & $\mathrm{~S}$ \\
\hline 1. Sinıf & 84 & 58.52 & 8.02 \\
2. Sinıf & 166 & 60.79 & 8.69 \\
3. Sinıf & 174 & 59.90 & 7.64 \\
4. Sinıf & 153 & 61.89 & 8.13 \\
\hline
\end{tabular}

Analiz sonuçları, araştırmaya katılan sınıf öğretmeni adaylarının medya okuryazarlık düzeylerinde sınıf düzeyleri bakımından anlamlı bir fark olduğunu göstermektedir, $\mathrm{F}(3,573)=3.52, \mathrm{p}<.05$. Sınıf düzeyleri arasındaki anlamlı farkın hangi sınıflar arasında olduğunu bulmak amaciyla yapılan Tukey testi sonuçlarına göre, anlamlı farkın 1. ve 4. sınıflar arasında 
olduğu ve farkın 4. sinıfların lehine olduğu görülmektedir. 4. sınıfların medya okuryazarlık düzeylerinin $(X=61.89) 1$. sinıfların medya okuryazarlık düzeylerinden $(X=58.52)$ daha yüksek olduğu belirlenmiştir.

Tablo 7. Adayların Medya Okuryazarlık Düzeylerinin Sınıf Düzeyine Göre ANOVA sonuçları

\begin{tabular}{lcccccc}
\hline \multicolumn{1}{c}{$\begin{array}{c}\text { Varyansın } \\
\text { Kaynağ1 }\end{array}$} & $\begin{array}{c}\text { Kareler } \\
\text { Top. }\end{array}$ & sd & $\begin{array}{c}\text { Kareler } \\
\text { Ort. }\end{array}$ & F & p & $\begin{array}{c}\text { Anlaml } \\
\text { Fark }\end{array}$ \\
\hline Gruplararasi & 701,33 & 3 & 233,77 & 3,52 &, 015 & \\
Gruplariçi & 37990,84 & 573 & 66,30 & & & $1-4$ \\
Toplam & 38692,17 & 576 & & & & \\
\hline
\end{tabular}

Adaylarn Gazete ve Dergi Takip Etme Alışkanlıklarn İle Medya Okuryazarlık Düzeyleri Arasındaki İlişki

Sınıf öğretmeni adaylarının medya okuryazarlık düzeyleri ile gazete ve dergi takip etme sıklıkları arasında anlamlı bir ilişki olup olmadığını belirlemek amacıyla yapılan çift serili korelasyon analizi sonuçları tablo $8^{\prime} \mathrm{de}$ gösterilmektedir.

Tablo 8. Medya Okuryazarlığı Düzeyi, Gazete ve Dergi Takip Etme Sıklıkları Arasındaki Korelasyon Sonuçları

\begin{tabular}{lccc}
\hline Değişkenler & 1 & 2 & 3 \\
\hline 1.Medya & \multirow{2}{*}{1.00} & $.11^{* *}$ & .02 \\
Okuryazarlığ1 & & 1.00 & $.21^{* *}$ \\
2. Gazete Takip & & & 1.00 \\
3. Dergi Takip & & & \\
\hline
\end{tabular}

**. Correlation is significant at the 0.01 level (2-tailed).

Tablo 8 sonuçlarına göre adayların medya okuryazarlığı düzeyleri ile gazete takip etme alışkanlıkları arasında anlamlı ve pozitif yönde bir ilişki olduğu görülmektedir $(\mathrm{r}=.11, \mathrm{p}<.01)$. Elde edilen sonuca göre adayların gazete takip etme sıklıklarının artması kısmen de olsa medya okuryazarlık düzeylerini olumlu yönde etkilediği söylenebilir. Adayların medya okuryazarlık düzeyleri ile dergi takip etme alışkanlıkları arasında pozitif bir ilişki olduğu ancak bu ilişkinin anlamlı olmadığı görülmektedir ( $\mathrm{r}=.02$, p>.01). Adayların dergi takip etme sıklıkları ile medya okuryazarlık düzeyleri arasındaki ilişkinin anlamlı çıkmamasında adayların takip ettikleri dergilerin niteliği etkili olabilirken, örneklem grubunda yer alan kadın adayların sayısının erkek adayların sayısından çok daha fazla olması da 
etkili olabilir. Adayların gazete takip etme sıklıkları ile dergi takip etme sıklıkları arasında anlamlı ve pozitif yönde bir ilişkinin olduğu görülmektedir $(\mathrm{r}=.21, \mathrm{p}<.01)$. Yani adayların gazete takip etme sıklıkları arttıkça dergi takip etme sıklıkları da artmaktadır.

\section{Adaylarn Gazete ve Dergi Takip Etme Siklıklarn Medya Okuryazarlık Düzeylerini Yordamakta mıdır?}

Sınıf öğretmeni adaylarının gazete ve dergi takip etme sıklıklarının medya okuryazarlık düzeylerini yordayıp yordamadığını belirlemek amacıyla yapılan lojistik regresyon analizi sonuçları tablo 9 da gösterilmektedir.

Tablo 9. Medya Okuryazarlık Düzeylerinin Yordanmasına İlişkin Regresyon Analizi Sonuçları

\begin{tabular}{lccccc}
\hline Değişken & B & $\begin{array}{c}\text { Standart } \\
\text { Hata в }\end{array}$ & $\beta$ & $t$ & $\mathrm{p}$ \\
\hline Sabit & 61,109 & 1,671 & & 36,564 &, 000 \\
Gazete &, 857 &, 303 &, 120 & 2,829 &, 005 \\
Dergi &, 434 &, 418 &, 044 & 1,038 &, 300 \\
\hline $\mathrm{R}=0.119$ & $\mathrm{R}^{2}=0.140$ & & & & \\
$\mathrm{~F}(2,574)=4.102$ & $\mathrm{p}=.000$ & & & & \\
\hline
\end{tabular}

Gazete ve dergi takip etme sıklığı değişkenleriyle bağımlı değişken arasındaki korelasyon incelendiğinde gazete ve dergi takip etme sıklığı ile medya okuryazarlık düzeyi arasında pozitif ve düşük düzeyde ilişkinin $(R=$ 0.12) olduğu görülmektedir. Gazete takip etme sıklığının adayların medya okuryazarlık düzeylerinin anlamlı bir yordayıcısı iken, $R=0.12, R^{2}=0.14$, $\mathrm{F}_{(2,574)}=4.102, \quad p<.01$; dergi takip etme sıklığının adayların medya okuryazarlık düzeylerinin anlamlı birer yordayıcısı olmadığı görülmektedir $\left(\mathrm{R}=0.12, \mathrm{R}^{2}=0.14, \mathrm{~F}_{(2,574)}=4.102, p>\right.$. 01). Medya okuryazarlık düzeylerine ilişkin toplam varyansın \%14'ünü adayların gazete ve dergi takip etme sıklıklarının açıklandığı söylenebilir.

\section{Tartışma, Sonuç ve Öneriler}

Sınıf öğretmen adaylarının gazete ve dergi takip etme alışkanlıkları ile medya okuryazarlık düzeyleri arasındaki ilişkiyi belirlemeyi amaçlayan bu araştırma 4 alt amaca cevap aramıştır. Bunlar; "(1) adayların gazete ve dergi takip etme sıklıkları, cinsiyetlerine ve sinıf düzeylerine göre anlamlı 
farklılık göstermekte midir? (2) adayların medya okuryazarlık düzeyleri cinsiyetlerine ve sınıf düzeylerine göre anlamlı farklılık göstermekte midir? (3) adayların medya okuryazarlık düzeyleri ile gazete ve dergi takip etme sıklıkları arasında anlamlı bir ilişki bulunmakta mıdır? (4) adayların gazete ve dergi takip sıklığı medya okuryazarlık düzeylerini yordamakta mıdır?" şeklindedir.

1. alt amaca yönelik yapılan analizler sonucunda kadın adayların erkek adaylardan anlamlı düzeyde daha sık gazete ve dergi takip ettiği bulgusuna ulaşılmıştır. Adayların sınıf düzeylerinin ise gazete ve dergi takip etme sıklıklarını anlamlı düzeyde etkilemediği görülmektedir. Saracaloğlu, Karasakaloğlu ve Aslantürk (2010) yaptıkları çalışmada kadın öğretmen adayların okuma ilgisinin erkek öğretmen adaylarından daha fazla olduğu bulgusuna ulaşmışlardır. Toruk (2008) çalışmasında kızların eğlenmek amacıyla \%60'ının gazete ve dergi takip ettiğini bu oranın erkeklerde \%40 olduğu sonucuna ulaşmıştır. Yine Can, Türkyılmaz ve Karadeniz (2010) ve Saracaloğlu, Bozkurt ve Serin (2003) çalışmalarında kızların okumaya karşı ilgisinin erkeklerden daha fazla olduğu sonucuna ulaşmışlardır.

Adayların medya okuryazarlık düzeylerinin cinsiyete göre anlamlı farklılık göstermediği görülmektedir. Benzer olarak Aktı (2011) tarafından yapılan çalışmada da katılımcıların cinsiyet değişkenine göre medya okuryazarlık düzeylerinde anlamlı farklılık bulunmamıştır. Adayların sınıf düzeylerine göre medya okuryazarlık düzeylerinin anlamlı farklılık gösterdiği ve 4 . sinıfların medya okuryazarlık düzeylerinin 1 . sinıfların medya okuryazarlık düzeylerinden daha yüksek olduğu bulunmuştur.

Araştırmaya katılan sınıf öğretmeni adaylarının gazete takip etme sıklıkları ile medya okuryazarlık düzeylerin arasında pozitif yönde ve anlamlı bir ilişkinin olduğu, yani gazete takip etme sıklıkları arttıkça medya okuryazarlık düzeylerinin de yükseldiği belirlenmiştir. Benzer olarak Sur, Ünal ve İşleri (2014) çalışmasında ilköğretim ikinci kademe öğrencilerinin günlük gazete okuma alışkanlıkların radyo dinleme alışkanlıkları ve medya okuryazarlık düzeyleri arasında anlamlı bir ilişki bulmuştur. Adayların dergi takip etme sıklıkları ile medya okuryazarlık düzeyleri arasında pozitif yönde bir ilişki olduğu ancak bu ilişkinin anlamlı olmadığı bulunmuştur. Adayların takip ettiği dergi türü bu sonucun çıkmasında etkili olduğu gibi araştırmaya katılan kadın aday sayısının erkek aday sayısından daha fazla olması da bu sonucun oluşmasında etkili olabilir. Adayların gazete takip etme sıklığı arttıkça dergi takip etme sıklığının da arttığı bulunan bir başka sonuçtur. Ünlüer (2008) sosyal bilgiler dersinde gazete kullanarak öğretim yapmanın öğrencilerin akademik başarılarını arttırdığını belirlerken, Bacaksız (2010) tarafından yapılan çalışmada medya okuryazarlığı dersi 
öğrencilerin gazete okuma alışkanlığından ziyade dergi okuma alışkanlıklarını arttııcı nitelikte olduğu sonucuna ulaşılmıştır. Adayların gazete okuma sıklıkları medya okuryazarlık düzeylerinin anlamlı birer yordayıcısı iken dergi okuma sıklıklarının medya okuryazarlık düzeylerini yordamadı̆̆ı görülmektedir.

Elde edilen sonuçlardan hareketle şu önerilerde bulunulabilir.

1. Adayların gazete takip etme alışkanlıkları ile onların medya okuryazarlık düzeyleri arasında pozitif yönde bir ilişki bulunmuştur. Öğrencilere bu alışkanlıkların ilkokuldan itibaren kazandırılması hem daha kolay hem de daha kalıcı olur. Bu bağlamda özellikle sınıf öğretmenlerine önemli görevler düşmekte ve öğrencilerine gazete takip etme alışkanlığı kazandıracak etkinlikler yaptırabilirler.

2. Sınıf öğretmenliği programının öğretmen adaylarının medya okuryazarlık düzeylerini olumlu yönde etkilediği bulunmuştur. Sınıf Öğretmenliği programına en azından seçmeli medya okuryazarlığı dersi konulması öğretmen adaylarının medya okuryazarlık becerilerini geliştireceği düşünülmektedir.

3. Araştırmada sınıf öğretmenliği adaylarının gazete ve dergi takip etme alışkanlıkları ile medya okuryazarlık düzeyleri arasındaki ilişki incelenmiştir. Eğitim fakültelerinin farklı programlarında benzer bir çalışma yapılarak sonuçlar karşılaştırılabilir.

\section{Kaynakça}

Aktı, S. (2011). İlköğretim sekizinci sınıf öğrencilerinin medya okuryazarlı̆̆ı ile sosyal beceri düzeyleri arasındaki ilişkinin belirlenmesi (Yüksek lisans tezi). Firat Üniversitesi, Elazı̆̆.

Altun, A. (2008). Türkiye'de medya okuryazarlığı. İlköğretmen Eğitimci Dergisi, 30 (34).

Altun, A. (2010). Kanada'daki medya okuryazarlığ1 üzerine bir değerlendirme, Abant İzzet Baysal Dergisi, 10 (2), 41 - 57.

Asrak Hasdemir, T. (2012). Gelenekselden yeni medya okuryazarlığına: Türkiye örneğinde bir değerlendirme. Hitit Üniversitesi Sosyal Bilimler Enstitüsü Dergisi, 5 (2), 23-40.

Bacaksız, T. (2010). Medya okuryazarlı̆̆ı dersinde gazete ve dergi kullanımı izmir'de medya okuryazarlı̆̆ dersinin öğrencilerin gazete ve dergi okuma alışkanlıklarına olan etkisi (Yüksek lisans tezi). Gazi Üniversitesi, Ankara.

Baykul, Y. ve Güzeller, C. O. (2014). Sosyal bilimler için istatistik SPSS uygulamalı (2. Baskı). Ankara: PegemA. 
Binark, M. ve Bek, G.M. (2007). Eleştirel Medya Okuryazarlğ̆ Kuramsal Yaklaşımlar ve Uygulamalar. İstanbul: Kalkedon.

Bozpolat, E. (2010). Öğretmen adaylarının okuma alışkanlığına ilişkin tutumlarının değerlendirilmesi (Cumhuriyet Üniversitesi Eğitim Fakültesi Örneği). Journal of World of Turks, 2 (1), 411-428.

Büyüköztürk, Ş., Kılıç Çakmak, E., Akgün, Ö. E, Karadeniz, Ş. Ve Demirel, F. (2011). Bilimsel Araştırma Yöntemleri (10. Bask1). Ankara: PegemA

Can, R., Türkyllmaz, M ve Karadeniz, A. (2010). Ergenlik dönemi öğrencilerinin okuma alışkanlıkları. Ahi Evran Üniversitesi Ĕ̆itim Fakültesi Dergisi, 11 (3), 1 - 21.

Collier, S., Folley, B., Moguel, D. \& Barnard, I., (2013). Write for your life: Developing dijital litaracies and writing pedagogy in teacher education. Contemporary Issues in Technology and Teacher Education, 13(3), 262-284.

Çakmak, E. (2010). Ingiltere ve Türkiye'deki ilköğretim medya okuryazarlığ eğitimi program ve uygulamalarının karşılaştırmalı olarak incelenmesi (Doktora tezi). Abant İzzet Baysal Üniversitesi, Bolu.

Çokluk, Ö., Şekercioğlu, G. ve Büyüköztürk, Ş. (2012). Sosyal bilimler için çok değişkenli istatistik SPSS ve LISREL uygulamaları. Ankara: PegemA.

Blumberg, F. C. Society for Media Psychology \& Technology [İnterview with Renee Hobbs: Media Literacy fort the 21st Century]. http://www.apa.org/divisions/div46/hobbs_interview.html

Karasar, N. (2011). Bilimsel Araştırma Yöntemi (22. Baskı). Ankara: Nobel.

Kellner, D. ve Share, J. (2005). Toward critical media literacy: core concepts, debates, organizations, and policy. Studies in The Cultural Politics of Education, 26 (3). 369-386.

Kıncal, R. Y. ve Kartal, O. Y. (2009). Medya okuryazarlığı eğitimi, Milli Eğitim Dergisi, 181, 318-333.

Korkmaz, Ö. ve Yeşil, R. (2011). Medya ve televizyon okuryazarlık düzeyleri ölçeği geçerlik ve güvenirlik çalışması, Uluslararası İnsan Bilimleri Dergisi,. 8 (2), 110-126.

Kress, G. (2003). Literacy In The New Media Age. London: Routledge.

Kubey, R. (1998). Obctacles to the development of media education in the united states. Journel of Communication, 48 (1), 58-69.

Livingstone, S. (2004). Media literacy and the challenge of new information and communication technolojies. The Communication Review 1,(7), 314.

Livingstone, S. (2008). Engaging with media a matter of literacy? Communication, Culture \& Critique, 1, 51-62. 
Özbay, M., Bağcl, H. ve Uyar, Y. (2008). Türkçe öğretmeni adaylarının okuma alışkanlığına yönelik tutumlarının çeşitli değişkenlere göre değerlendirilmesi. İnönü Üniversitesi Eğitim Fakültesi Dergisi. 9 ,(15), s.117-136.

Saracaloğlu, A. S., Bozkurt, N. ve Serin, O. (2003). Üniversite öğrencilerinin okuma ilgileri ve okuma alışkanlıklarını etkileyen faktörler. Eğitim Araştırmaları Dergisi. 4 (12).

Saracaloğlu, A.S. , Karasakaloğlu, N. ve Aslantürk, E. (2010). Sınıf öğretmeni adaylarının okuma ilgi ve alışkanlıklarının karşılaştırılması: Adnan Menderes ve Uludağ üniversitesi örneği. Ç.Ü. Sosyal Bilimler Enstitüsü Dergisi, 19 (3), $457-480$.

Semali, L. \& Hammett R. (1998). Critical media literacy: content or process? Review of Education, Pedagogy, and Cultural Studies, 20 (4), 365 - 384.

Stein, L. \& Prewett, A. (2009). Media literacy education in the social studies: Teacher perceptions and curricular challenges. Teacher Education Querterly, 36 (1), 131-148.

Sur, E., Ünal, E. ve İşler, K. (2014). Primary school second grade teachers' and students' opinion on media literacy. Media Education Research Journal, 21 (42), 119-127. Doi:10.3916/C42-2014-11

Teo, P. (2014). Making a familier strange and the strange familiar: a project for teaching critical reading and writing. Lenguage and Education, 28 (6), 539-551.

Thoman, E. (1999). Skills and strategies for media education. Educational Leadership, 56 (5), 50-54.

Ünlüer, G. (2008). Sosyal Bilgiler Dersinde Gazete Kullanımının Öğrencilerin Akademik Başarllarına ve Tutumlarma Etkisi (Doktora Tezi), Anadolu Üniversitesi: Eskişehir. 
E. YILMAZ, S. ALADA $\breve{G} \mid 16$ 